\author{
MaŁgorzata Mizielińska, ŁukAsz Łopusiewicz, Marcin Soból
}

Centrum Bioimmobilizacji i Innowacyjnych Materiałów Opakowaniowych Zachodniopomorski Uniwersytet Technologiczny $w$ Szczecinie Klemensa Janickiego 35, 71-270 Szczecin E-mail: malgorzata.mizielinska@zut.edu.pl

\title{
POLIHYDROKSYALKANOLANY - OBIECUJĄCE POLIMERY BIODEGRADOWALNE
}

\section{WSTEP}

Tworzywa sztuczne pełnia ważną rolę w życiu każdego człowieka. Sa obecne niemal w każdej dziedzinie życia. Początek dynamicznego rozwoju technologii produkcji tworzyw sztucznych datuje się na lata 50. XX w. (KAUR i współaut. 2017). Zastapiły one częściowo używane od wieków drewno, szkło i metale, znaczaco umacniajac swoja pozycję jako jeden $z$ podstawowych materiałów inżynierskich. Postęp w dziedzinie chemii polimerów, dzięki bardziej efektywnym procesom syntezy, umożliwił produkcję wyrobów trwałych i odpornych na degradacje (chemiczna i mikrobiologiczna). Przez kilka dekad tworzywa sztuczne postrzegane były jako rewolucyjne rozwiazanie w przemyśle, pokonujace szereg problemów, $z$ którymi wiąało się użytkowanie innego typu materiałów. Komercyjne, syntetyczne tworzywa polimerowe maja mniejszą gęstość niż szkło, są od niego również dużo bardziej odporne mechanicznie dzięki mniejszej sztywności. W porównaniu do materiałów metalowych, nie koroduja i są w przeważającej większości mniej lub bardziej przeźroczyste. Poza tym, łatwość zadruku, ogromna różnorodność form konstrukcyjnych, przy równoczesnej możliwości łaczenia ich $z$ innymi materiałami (np. laminowanie), stanowia ogromny walor użytkowy tworzyw sztucznych. Niska, konkurencyjna w stosunku do innych klasycznych materiałow, cena popularnych tworzyw sztucznych $z$ grupy poliolefin i poliestrów, spowodowała szybki wzrost ich zastosowań w wielu dziedzinach. Jednak po latach zaczęto zauważać ich wady (w zwiazku ze wzrostem świado- mości środowiskowej), szczególnie z punku widzenia zasad ekologii. Niestety, przez brak podatności na biodegradację polimery syntetyczne oddziałuja negatywnie na środowisko, obciążając je w znacznym stopniu. Dlatego, w trosce o środowisko coraz częściej stosuje się biopolimery. Polihydroksyalkanolany (PHA) to naturalne polimery produkowane przez szereg mikroorganizmów i zmodyfikowane genetycznie rośliny (STEINBÜCHEL 2003, KAUR i współaut. 2017). Maja one postać granulek występujacych w cytoplazmie bakterii. Granule te stanowia materiał zapasowy, który wykorzystywany jest przez drobnoustroje przy niedoborze składnikow odżywczych, takich jak azot, fosfor i siarka, przy jednoczesnym nadmiarze źródeł węgla. Stanowia doskonała alternatywę dla polimerów syntetycznych, ponieważ mają podobne do nich właściwości, ale w przeciwieństwie do nich ulegaja całkowitemu biorozkładowi. Obecnie koszty produkcji biodegradowalnych polimerów sa niestety zbyt wysokie w porównaniu $z$ tworzywami sztucznymi, jednak ciagłe trwaja prace nad znalezieniem sposobów na ich obniżenie (KosIoR i współaut. 2006).

\section{BUDOWA I WŁAŚCIWOŚCI PHA}

W grupie PHA wyróżnione zostały dwie podgrupy. Do pierwszej zaliczamy poliestry krótkołańcuchowe (ang. short chain lenght, $\left.\mathrm{PHA}_{\mathrm{SCL}}\right)$, których monomery zawieraja w swojej budowie 3-5 atomów węgla. Druga podgrupa sa PHA, których monomery zawierają od 6-16 atomów węgla. Określa się je jako średniołańcuchowe (ang. medium chain 
lenght $\left.\mathrm{PHA}_{\mathrm{MCL}}\right)$. Jednym $\mathrm{z}$ głównych przedstawicieli PHA jest poli(hydroksyoktanian-co-hydroksykaprynian), P(HO-co-HD) [ang. poly(hydroxyoctanoate-co-hydroxydecanoate)]. PHA zawieraja łańcuchy nasycone lub nienasycone. Poliestry $\mathrm{PHA}_{\mathrm{SCL}} \mathrm{i} \mathrm{PHA}_{\mathrm{MCL}}$ różnia się właściwościami fizycznymi. Niewiele bakterii jest zdolnych do syntezy PHA, które składają się zarówno $z$ PHA $_{\mathrm{SCL}}$ i $\mathrm{PHA}_{\mathrm{MCL}}$ (DOI i współaut. 1995).

Jeden $z$ najczęściej wykorzystywanych w przemyśle PHA, polihydroksymaślan (ang. polyhydroxybutyrate, PHB), wykazuje spore podobieństwo do polipropylenu, ponieważ jest polimerem termoplastycznym. Jest jednak bardziej sztywny i łamliwy, $z$ powodu większej krystaliczności. Aby poprawić właściwości fizyczne i zmniejszyć krystaliczność tworzy się kopolimery hydroksymaślanianu (ang. 3-hydroxybutyrate, 3HB) i hydroksywalerianianu (ang. 3-hydroxyvalerate, 3HV), które zaliczane sa do podgrupy $\mathrm{PHA}_{\mathrm{SCL}}$. Dodanie 20\% mol monomerów 3HV do PHB powoduje obniżenie temperatury zeszklenia i modułu Younga PHB, co umożliwia przetwarzanie tego biopolimeru w temperaturach niższych od temperatury ich rozkładu, co oznacza uzyskanie właściwości termoplastycznych (CHEN i współaut. 2001).

Właściwości fizyczne i chemiczne PHA zależą od mikroorganizmu użytego do ich produkcji oraz od źródła węgla, jakie zostało wykorzystane podczas hodowli. Średnia masa cząsteczkowa głównego przedstawiciela PHA, tj. kwasu poli-3-hydroksymasłowego, wynosi od $6 \times 10^{5}$ do $1,6 \times 10^{6} \mathrm{~g} / \mathrm{mol}$. Po jego ekstrakcji krystaliczność sięga od 55\% do $80 \%$. Temperatura zeszklenia tego biopolimeru wynosi $\mathrm{t}_{\mathrm{g}}=4^{\circ} \mathrm{C}$ (temperatura, w której następuje przejście ze stanu ciekłego lub plastycznego w stan szklisty, czego objawem jest skokowy wzrost lepkości substancji; ang. glass transition), a temperatura topnienia $t_{m}=180^{\circ} \mathrm{C}$ (ang. melting temperature). Cechuje go także wytrzymałość na zerwanie (40 MPa) oraz moduł Younga (wielkość określająca sprężystość materiału) o wartości 3,5
GPa. Sa to właściwości bardzo zbliżone do polipropylenu (PP). Różnica jest natomiast znacząca przy wydłużeniu na zerwanie PHB, wynoszaca zaledwie $5 \%$, podczas gdy dla PP parametr ten wynosi 150-600\%. Dzięki temu, że temperatura topnienia (ok. $175^{\circ} \mathrm{C}$ ) bardzo różni się od temperatury rozkładu termicznego, nie naraża to struktury polimeru na uszkodzenia podczas jego przetwarzania. Poprawę właściwości można uzyskać wykonując blendy (mieszanki polimerowe) z innymi polimerami podczas jego przetwórstwa lub poprzez dodanie plastyfikatorów (MADISON i HUISMAN 1999, KAUR i współaut. 2017). Zestawienie wybranych właściwości PHA, w porównaniu do właściwości powszechnie stosowanych tworzyw sztucznych, przedstawia Tabela 1 .

\section{MIKROOGRANIZMY PRODUKUJACE PHA}

Znanych jest wiele mikroorganizmów zdolnych do produkcji PHA. Już w latach 30. XX w. odkryto zdolność różnych bakterii do wewnętrznego magazynowania węgla i energii w postaci PHB (1925 r. u Bacillus megaterium przez Lemoignea) (KAUR i współaut. 2017). Wykazano zdolność produkcji PHA przez mikroorganizmy $z$ wielu grup, włączajac w to eubakterie (np. rodzaje Pseudomonas, Bacillus, Citrobacter, Enterobacter, Klebsiella, Escherichia, Ralstonia), sinice i archeony. Synteza PHB jest rozpowszechniona $\mathrm{u}$ bakterii wiażacych azot czassteczkowy, np. Rhizobium, Azotobacter (A. beijernickii, A. macrocytogenes, A. vinelandii). Do produkcji PHB zdolne sa niektóre metylotrofy, jednak produkuja go w małych ilościach (SUZUKI i współaut. 1986, KAUR i współaut. 2017). Mikroorganizmy zostały podzielone na dwie grupy, w zależności od warunków hodowli niezbędnych do otrzymania PHA. Pierwsza grupa sa drobnoustroje, wymagające nadwyżki źródła węgla w pożywce oraz ograniczonego poziomu tlenu i źródeł azotu (warunki stresowe) (np. Cupravidus necator

Tabela 1. Porównanie wybranych właściwości PHA i innych tworzyw sztucznych.

\begin{tabular}{llllll}
\hline Polimer & $\begin{array}{l}\text { Temperatura } \\
\text { zeszklenia }\left[{ }^{\circ} \mathrm{C}\right]\end{array}$ & $\begin{array}{l}\text { Temperatura top- } \\
\text { nienia }\left[{ }^{\circ} \mathrm{C}\right]\end{array}$ & $\begin{array}{l}\text { Wytrzymałość na } \\
\text { rozciaganie }[\mathrm{MPa}]\end{array}$ & $\begin{array}{l}\text { Moduł Younga } \\
{[\mathrm{GPa}]}\end{array}$ & $\begin{array}{l}\text { Wydłużenie przy } \\
\text { zerwaniu }[\%]\end{array}$ \\
\hline PHA & 4 & 180 & 40 & 3,5 & 5 \\
LDPE & -90 & 137 & 7 & $0,11-0,45$ & 500 \\
HDPE & -110 & 115 & 37 & 0,8 & 600 \\
PP & -14 & 176 & $19,7-80$ & $1,5-2$ & $150-600$ \\
PCW & 87 & 212 & 16 & $2,4-4,1$ & $2-30$ \\
PS & 100 & 239 & $32-44$ & $3-3,5$ & $1,8-40$ \\
\hline
\end{tabular}

PHA, polihydroksyalkanolany; LDPE, polietylen o niskiej gęstości; HDPE, polietylen o dużej gęstości; PP, polipropylen; PCW, polichlorek winylu; PS, polistyren. 
(syn. Ralstonia eutropha), Protomonas extorquens i $P$. oleovorans). Druga grupe stanowia mikroorganizmy, które nie wymagaja limitacji związków odżywczych, a PHA kumuluja w fazie wykładniczego wzrostu (np. Alcaligenes latus, A. vinelandii, rekombinowana E. coli) (KHANNA i SRIVASTAVA 2005).

Cyjanobakterie (sinice) sa zdolne do produkcji PHB $z$ dwutlenku węgla (źródło węgla) $z$ udziałem energii światła słonecznego, dzięki enzymowi syntazie PHA. Wśród wielu gatunków, dwa szczepy, Spirulina platensis UMACC 161 (JAU i współaut. 2005) i Synechocystis sp. PCC6803 (SUDESH i wspó1aut. 2001), moga gromadzić PHB w ilości ok. $10 \%$ suchej masy komórek. Zwraca się uwage na potencjalnie korzystne stosowanie sinic do produkcji PHA, ponieważ wykorzystanie energii słonecznej pozwala znacznie obniżyć koszty produkcji, jednocześnie przyczyniając się do obniżenia zawartości dwutlenku węla w atmosferze (KAUR i współaut. 2017).

Wśród archeonów zdolnych do produkcji PHA największa uwage zwracaja organizmy halofilne (żyjace w zasolonych środowiskach), które do hodowli nie wymagaja ściśle sterylnych warunków, $z$ uwagi na wysokie stężenie soli (wymagane do zachowania stabilności ściany komórkowej), eliminujace niepożądana mikroflorę. W niskich stężeniach soli lub jej braku (szczególnie w wodzie destylowanej) ściana komórkowa halofili ulega dezintegracji, uwalniając treść komórki na zewnątrz, co ułatwia pozyskanie PHA. Do rodzajów halofilnych archeonów, które produkuja PHA, należą m.in. Haloferax, Haloarcula, Haloquadratum, Haloalkalicoccus, Natrinema, Natronobacterium, Halopiger, Halococcus (TEKIN i współaut. 2012, KAUR i współaut. 2017).

Ze względu na wysokie koszty produkcji i oczyszczania PHA, w przemyśle wykorzystuje się tylko takie mikroorganizmy, które magazynuja ponad $80 \%$ tego biopolimeru. Sa to: Ralstonia eutropha, Alcaligenes latus, Azotobacter vinelandii, rekombinowana genetycznie Escherichia coli, Methylobacterium organophilum i Pseudomonas putida (LUENGO i współaut. 2003, KUNASUNDARI i SUDESH 2011).

Pożywkę dla drobnoustrojów stanowia niskocząsteczkowe kwasy organiczne oraz glukoza i fruktoza. A. latus bardzo często wykorzystuje sacharozę i bardziej złożone związki organiczne, występujace w serwatce i melasie. M. organophilum, w obecności metanolu, syntetyzuje kwas poli-3-hydroksymasłowy. Substratem dla P. putida jest fruktoza, glukoza lub glicerol. Oprócz homopolimerów, mikroorganizmy sa zdolne do kumulowania kopolimerów, czyli polihydroksykwasów za- wierających przynajmniej dwa różne mery. Homopolimery i kopolimery PHA, można wytwarzać w zależności od gatunków bakterii i warunków wzrostu.

Znane sa także inne możliwości wytwarzania PHA; ciekawym przykładem sa transgenicznie zmodyfikowane rośliny takie jak: Arabidopsis thaliana, która kumuluje PHA w plastydach, bawełna, kukurydza oraz rośliny oleiste np. rzepak (STEINBÜCHEL 2003).

\section{GENETYCZNA REGULACJA PRODUKCJI PHA}

O tym, czy zostana wyprodukowane polimery o krótkich czy długich łańcuchach, decyduje rodzaj aparatu genetycznego, który jest odpowiedzialny za syntezę i kumulację PHA. Istnieja trzy główne klasy loci PHB. Locus pierwszej klasy (typ I) składa się $z$ trzech genów kodujacych odpowiednio: polimerazę PHA (phbC), $\beta$-ketotiolazę (phaA) katalizujaca syntezę acetylokoenzymu A i reduktazę acetylokoenzymu A $(p h b B)$, która redukuje acetylokoenzym A do R-3-hydroksymaślanokoenzymu A. Do drugiej klasy (typ II) należy locus składający się $z$ dwóch różnych genów kodujących odpowiednio polimeraze PHA (phaC1 $i$ phaC2), przedzielonych genem kodującym depolimerazę PHA (phaZ). Typ ten jest charakterystyczny dla rodzaju Pseudomonas. Trzecia klase (typ III) tworzy locus składający się $z$ dwóch genów (phbE i phbC), kodujacych dwie podjednostki polimerazy PHA; ten typ stwierdzono u Chromatium vinosum, Thiocystis violecea. Mikroorganizmy posiadajace locus PHA typu I i III gromadzą polihydroksykwasy o krótkim łańcuchu węgla, natomiast należace do typu II kumuluja polihydroksykwasy o średniej długości łańcucha (LUENGo i współaut. 2003).

\section{PRODUKCJA PHA PRZEZ RALSTONIA EUTROPHA}

Ralstonia eutropha należy do głównych producentów PHA. W warunkach przemysłowych komórki bakteryjne sa namnażane wstępnie na podłożu zawierającym glukozę jako główne źródło węgla. Mikroorganizmy sa inkubowane przez 2 tygodnie w warunkach chłodniczych, a 12 godzin przed rozpoczęciem procesu syntezy PHA wysiewa się je na płynne podłoże $z$ glukoza $i$ inkubuje $\mathrm{w} 30^{\circ} \mathrm{C}$. Po inkubacji mikroorganizmy przenosi się do fermentatora $z$ napowietrzaniem, zawierającego pożywkę $z$ glukoza, gdzie namnażają się przez 12 godzin w temperaturze $30^{\circ} \mathrm{C}$. Następnie hodowlę przenosi się do bioreaktora przemysłowego (np. o pojemności 20.000 litrów). Proces fermentacji składa się z dwóch etapów przeprowadzanych w ści- 
śle określonych warunkach (napowietrzanie, pH, dostępność źródel wegla, azotu, fosforu): fazy wzrostu mikroorganizmów i fazy produkcji biopolimeru. W konsekwencji osiaga się 45-80\% zawartości PHA w suchej masie (CHEN i współaut. 2001, LUENGO i współaut. 2003, SteinBÜCHEL 2003, CIESIELSKI i współaut. 2008, ANIS i współaut. 2013).

\section{MODYFIKACJA SKŁADU PODŁOŻA HODOWLANEGO A STRKTURA ŁANCUCHA PHA}

Istotna zaleta mikrobiologicznych metod otrzymywania PHA jest możliwość projektowania polimerów kumulowanych przez mikroorganizmy. Można tego dokonać przez zamianę źródła węgla. Udowodniono, że gdy tym źródłem jest ester kwasu masłowego, wówczas kumulowany jest homopolimer kwasu 3-hydroksymasłowego. Gdy jako źródło węgla zostana wykorzystane kwasy organiczne o parzystej liczbie atomów węgla (np. kwas octowy), syntetyzowany będzie kwas poli-3-hydroksymasłowy (PADOVANI i współaut. 2016). Fakt ten wzbudził zainteresowanie głównie $\mathrm{w}$ przemyśle, ponieważ przez zmianę składu źródła węgla można otrzymać PHA o odmiennych właściwościach fizycznych i chemicznych. Typowym przykładem jest wykorzystanie bakterii Alcaligenes eutrophus do produkcji wybranych PHA. Jeżeli podczas wytwarzania biopolimeru źródłem węgla jest glukoza to syntetyzowany jest PHB. Przez zmianę źródła węgla, np. na kwas propionowy, w komórkach A. eutrophus powstaje 3-hydroksymaślan i 3-hydroksywalerianian (3HB-co-3HV). Kopolimer jest bardziej elastyczny niż homopolimer PHB (im wyższa zawartość HV tym bardziej elastyczny produkt) $z$ powodu ograniczonej krystaliczności i jest odpowiedni do procesu wytłaczania, podczas gdy czysty PHB lub kopolimer $z$ niska zawartościa (4\%) HV wykorzystywany jest do przetwarzania za pomoca wtrysku (DoI i współaut. 1995, CHEN i współaut. 2001). Komercyjnym przedstawicielem kopolimerów o różnej zawartości HV $\mathrm{w}$ monomerze jest produkt BIOPOL.

\section{WYTWARZANIE PHA PRZEZ REKOMBINOWANE KOMÓRKI E. COLI}

Do otrzymania rekombinowanych pałeczek E. coli wytwarzajacych PHA, jako donor plazmidów zawierających geny szlaku biosyntezy PHA, wykorzystywany jest główny producent tego biopolimeru, Ralstonia eutropha. Rekombinowane bakterie moga metabolizować zarówno glukozę, jak i kwas propionowy, do otrzymywania homopolimerów i/lub kopolimerów PHA. Istotna zaleta wykorzystania modyfikowanych genetycznie szczepów jest to, że $\mathrm{w}$ przeciwieństwie do $R$. eutropha, nie posiadaja one zdolności do przyswajania dimerów R3HB (ang. R-3-hydroxyburytic acid), które moga być wbudowywane $\mathrm{w}$ łańcuch biopolimeru. Prowadzi to do zwiększenia wydajności procesu i uzyskania $\mathrm{w}$ suchej masie aż 90\% PHB lub jego kopolimeru z HV (LEE 1996, PARK i współaut. 2004).

\section{POZYSKIWANIE PHA Z OSADU CZYNNEGO}

Ze względu na wysokie koszty produkcji PHA z wykorzystaniem mikroorganizmów, coraz częściej prowadzone sa badania majace na celu ich obniżenie. Aby proces biosyntezy przebiegał ekologicznie i koszty nakładu były jak najniższe, istnieje możliwość otrzymywania PHA $z$ osadu czynnego. Daje to możliwość wykorzystania jako surowców produktów ubocznych i odpadów przemysłu rolno-spożywczego. Proces ten może być prowadzony zarówno w warunkach tlenowych, jak i beztlenowych. Kolejnym atutem wykorzystania osadu czynnego jest fakt, że nie ma potrzeby utrzymywania sterylnych warunków podczas hodowli. Istotna jest także jego wysoka stabilność, dzięki naturalnej selekcji gatunkowej mikroorganizmów. MUSZYŃSKI i współaut. (2013) podjęli się próby otrzymania PHA z osadu czynnego, wykorzystując różne podłoża. W warunkach limitowanego stężenia tlenu, kumulacja kwasu poli-3-hydroksymasłowego w osadzie czynnym wynosiła od $20 \%$ do 30\%. Można było jednak zwiększyć zawartość $\mathrm{P}(3 \mathrm{HB})$ [ang. poly(3-hydroxybuturate)] do $40 \%$ wprowadzajac do ścieków kwas octowy, który jest tanim źródłem węgla. Na skalę przemysłowa pozyskiwać go można $z$ fermentacji osadów ściekowych. Uzyskana podczas eksperymentu ilość biopolimerów (40\% zawartość w suchej masie) była jednak zbyt mała, by można było stosować je komercyjnie. Kiedy $\mathrm{w}$ procesie otrzymywania PHA wykorzystuje się osad czynny, ich biosynteza może być stymulowana przez zmienność warunków tlenowych lub ograniczenie pierwiastków biogennych (azotu i fosforu), przy nadmiarze wegla organicznego. Stosunek C:N przy kumulacji PHA $z$ osadu czynnego jest bardzo zróżnicowany, może wynosić 50:1 lub nawet 144:1 (KHARDENAVIS i współaut. 2005).

\section{POZYSKIWANIE PHA Z PRODUKTÓW ODPADOWYCH PRZEMYSEU ROLNO-SPOŻYWCZEGO}

Rosnace zaniepokojenie negatywnymi skutkami dla środowiska, zwiazanymi $z$ użytkowaniem tworzyw sztucznych, dało impuls 
do poszukiwania alternatywnych biodegradowalnych biopolimerów. Jednak do wytworzenia ekonomicznie opłacalnego biodegradowalnego polimeru, konieczne jest zwrócenie uwagi na koszty i wydajności jego pozyskiwania w porównaniu do tworzyw sztucznych. Koszty substratów do produkcji PHA i ich oczyszczanie sprawiaja, że mimo swoich niewatpliwych zalet, sa one zbyt drogie, w porównaniu do polimerów syntetycznych. Koszt źródła węgla do mikrobiologicznego procesu produkcji PHA może stanowić nawet do 50\% kosztów całkowitych. Jednym $z$ rozwiazań obniżajacych koszty produkcji wydaje się być zastosowanie odpadów $z$ produkcji rolno-spożywczej jako taniego, łatwo dostępnego źródła węgla i azotu (KAUR i współaut. 2017).

Wiele odpadów przemysłu rolno-spożywczego może służyć jako pożywka dla mikroorganizmów do produkcji PHA. Wykorzystywane sa $\mathrm{m}$. in. melasy $\mathrm{z}$ buraków (produkcja 36 g PHA/L przez A. vinelandii) lub $z$ trzciny cukrowej $(60 \%$ suchej masy komórek $P$. aeruginosa) (CHEN i PAGE 1997, LAW i wspó1aut. 2001, TRIPATHI i współaut. 2012, KAUR i współaut. 2017). Stosowana jest także serwatka i jej hydrolizaty $(96,2$ g PHA/L przez rekombinowana $E$. coli CGSC 4401 posiadajaca geny $z$ A. latus) (FONESCA i ANTONIO 2006). Obiecujacym odpadem sa materiały ligninocelulozowe (m. in. siano, otręby, trociny, łupiny), jednak często wymagaja wstępnej obróbki, celem uwolnienia łatwiej przyswajalnych przez mikroorganizmy prostszych źródeł węgla (np. cukrów) (KAUR i współaut. 2017). Dość powszechnie wykorzystywanym substratem jest glicerol odpadowy, powstajacy $\mathrm{m}$. in. przy produkcji biopaliw (BORMANN i ROTH 1999, KAUR i współaut. 2017). Mikroorganizmy wykorzystywane do przemsłowej produkcji PHA, coraz częściej jako źródło węgla wykorzystuja kwasy tłuszczowe, będące odpadami przemysłu spożywczego. Kwasy tłuszczowe dostarczają więcej energii, $w$ porównaniu $Z$ węglowodanami, jednak największym wyzwaniem w ich stosowaniu jest ich hydrofobowy charakter. Wykorzystuje się szerokie spektrum substratów tłuszczowych, m. in. olej kokosowy, palmowy, oliwę, olej kukurydziany $i$ inne tłuszcze roślinne i zwierzęce (m. in. łój). Wiele bakterii, m.in. z rodzajów: Pseudomonas, Caulobacter, Ralstonia, Acinetobacter, Sphingobacterium, Burhkholderia, Yorkenella, jest $\mathrm{w}$ stanie wykorzystywać te substraty do produkcji PHA (SAHARAN i współaut. 2014, KAUR i współaut. 2017).

\section{OCZYSZCZANIE PHA}

Ponieważ PHA produkowane przez drobnoustroje sa kumulowane wewnatrzkomórkowo, do wykorzystania w przemyśle bio- polimery te trzeba wyodrębnić, a następnie oczyścić. Ze względu na dużą różnorodność zastosowania PHA, wymagana jest różna czystość produktu końcowego. Jeżeli PHA maja być przeznaczone do celów medycznych, czystość ich musi być bardzo wysoka, gdyż obecność związków chemicznych - pozostałości po biomasie bakteryjnej [takich jak LPS (lipopolisacharyd) bakterii Gram ujemnych], może stanowić niepożądane zanieczyszczenie. Natomiast w sytuacji, w której produktem końcowym maja być worki czy opakowania przeznaczone, np. dla przemysłu rolniczego, PHA nie musi być wysokiej klasy czystości (KunASUNDARI i SudESH 2011). Należy jednak podjąć działania prowadzące do oddzielenia granulek biopolimeru od zanieczyszczeń takich jak: kwasy nukleinowe, lipidy, fosfolipidy, peptydoglikany czy czasteczki białkowe (ANIS i współaut. 2013).

Proces ekstrakcji PHA poprzedza się tzw. obróbka biomasy. Jest to działanie mające na celu podwyższenie wydajności procesu oraz końcowej czystości biopolimeru i polega na wstępnym potraktowaniu komórek bakterii pewnymi zwiazkami chemicznymi, takimi jak $\mathrm{NaCl}$ czy $\mathrm{H}_{2} \mathrm{O}_{2}$. Najczęściej używa się jednak $\mathrm{NaCl}$, gdyż destabilizuje on ścianę komórkową, co w rezultacie sprawia, że jest ona łatwiejsza do zniszczenia. Chlorek sodu podwyższa ciśnienie osmotyczne, co doprowadza do odwodnienia bakterii i ułatwienia uwolnienia granulek PHA w wyniku późniejszego działania na ścianę komórkowa roztworem NaOH (ANIS i współaut. 2013).

Oprócz obróbki chlorkiem sodu można wyróżnić także obróbkę cieplna, która zmniejsza stabilność ściany komórkowej bakterii. Ponadto, pod wpływem ciepła zachodzi denaturacja białek i materiału genetycznego, co ułatwia późniejszy proces oczyszczania. W zależności od rodzaju bakterii, obróbka może różnić się zakresem temperatur i czasem trwania tego procesu. Na przykład bakterie $z$ rodzaju Pseudomonas poddaje się działaniu $120^{\circ} \mathrm{C}$ przez 1 minutę, a Ralstonia eutropha $85^{\circ} \mathrm{C}$ przez 15 minut. Inny sposób obróbki to zamrażanie komórek. Sprawia to, że PHA i składniki budujace ścianę komórkowa sa łatwiej rozkładane przez SDS (siarczan dodecylu sodu) i podchloryn sodu. Zamrażanie do $-20^{\circ} \mathrm{C}$ wykorzystuje się także do dłuższego przechowywania komórek (JACQUEL i współaut. 2008).

Znanych jest wiele metod oczyszczania PHA. Wybór metody zależy od ilości oczyszczanego polimeru, oraz czystości polimeru, jako produktu końcowego. Metody chemiczne i enzymatyczne cechuja się wysoka wydajnościa procesu oczyszczania. Uzyskuje się czyste granulki PHA o wysokiej średniej masie cząsteczkowej. Bardzo często podczas wy- 
odrębniania granulek biopolimeru z komórki wykorzystuje się: chloroform, trifluoroetanol, dichloroetanol, węglan propylenu, chlorek metylenu, kwas dichlorooctowy (KUNASUNDARI i SUDESH 2011). Ciężar czasteczkowy oczyszczanych w ten sposób materiałów wynosi od 50 do $100 \mathrm{kDa}$. Jednak rozpuszczalniki te maja negatywny wpływ na środowisko. Stosowanie enzymów (proteaz, celulaz, lizozymu) jest korzystniejsze $z$ ekologicznego punktu widzenia, niestety pociaga za soba wysokie koszty oczyszczania (DE KONIG i Witholt 1997). Mechaniczne metody wyodrębniania PHA sa szeroko używane w przemyśle, zwłaszcza farmaceutycznym oraz biotechnologicznym, gdzie wymagana jest wysoka czystość produktu. Brak wykorzystania rozpuszczalników chemicznych oznacza, że metody te sa przyjazne środowisku. Dodatkowo, nie powoduja poważnych uszkodzeń polimerów. Nie sa to jednak idealne metody odzyskiwania PHA, gdyż konieczny jest duży wkład inwestycyjny podczas projektowania i budowy instalacji, ponadto metody te sa czasochłonne. Dlatego coraz częściej podczas wyodrębniania PHA $z$ komórek bakteryjnych łączy się metody chemiczne i mechaniczne (KUNASUNDARI i SUDESH 2011, KAUR i współaut. 2017). Jedna $z$ metod oczyszczania granulek PHA jest ekstrakcja za pomoca płynów w stanie nadkrytycznym (ang. supercritical fluid, $\mathrm{SCF}$ ), np. $\mathrm{H}_{2} \mathrm{O}, \mathrm{CO}_{2}$. Wyjatkowe właściwości fizykochemiczne takiego płynu, tj.: wysoka gęstość, niska lepkość, niepalność, nietoksyczność, możliwość łatwego usuwania $z$ produktu, czynia go dobrym rozpuszczalnikiem. Ponadto, jest to metoda prosta, niedroga, szybka i co najważniejsze, przyjazna środowisku (KUNASUNDARI i SUDESH 2011). Jak dotad nie znaleziono jednak takiej metody, która byłaby jednocześnie tania, prowadziłaby do otrzymania PHA o wysokiej czystości, a zarazem była przyjazna środowisku. Jest to jeden $z$ głównych powodów, dlaczego materiały $z$ PHA nie wyparły jeszcze produktów syntetycznych otrzymywanych ze zwiazków pochodzenia naftowego.

\section{ZASTOSOWANIE PHA I PRODUKTY KOMERCYJNE}

Zastosowanie PHA uzależnione jest od ich średniej masy cząsteczkowej (Mn) i zawartości molowej komonomerów (ang. 4-hydroxybutyrate, 4HB; ang. 3-hydroxyhexanoate, $3 \mathrm{HV}, 3 \mathrm{HHx}$ ) w kopoliestrach typu PHBV i PHBHx. PHA o niskiej zawartości komonomerów (do 5\%) i względnie niskiej $\mathrm{Mn}=500000 \mathrm{~g} / \mathrm{mol}$ ze względu na to, że sa twarde i sztywne, sa przetwarzane za pomoca wtrysku. Stosowane sa zatem do produkcji materiałów opakowaniowych takich jak: tacki, kubeczki jednorazowe, łyżeczki, talerzyki. Natomiast PHA o $\mathrm{Mn}=600000 \mathrm{~g} / \mathrm{mol}$ moga być wykorzystywane do produkcji włókien, służących do otrzymywania nici chirurgicznych i odzieży wykorzystywanej na sali operacyjnej (biodegradowalnej). Kopolimery, w których zawartość HV wynosi ponad 10\%, ze względu na swoje właściwości termoplastyczne moga być przetwarzane w procesach wytłaczania. W ten sposób wytwarzane moga być folie stosowane między innymi w rolnictwie. Poliestry o $\mathrm{Mn}=600000-700000$ $\mathrm{g} / \mathrm{mol}$ sa stosowane do produkcji opakowań sztywnych metoda wtrysku $z$ rozdmuchem (butelki) i termoformowania, oraz worków na odpady metoda wytłaczania $z$ rozdmuchem. Biopolimery, $z$ zawartościa HV w kopolimerze z HB powyżej 15\%, sa bardzo elastyczne i można je wykorzystać jako kleje lub do produkcji folii elastycznych (KONDRATOwICZ 2010).

Ze względu na swoje właściwości fizyczne, mechaniczne, biokompatybilność, PHA znalazły zastosowanie w biomedycynie. Bardzo korzystne sa implanty wykonane $z$ PHA, ze względu na ich biodegradacje in vivo, która minimalizuje ryzyko wystapienia infekcji. Istotna zaleta tych polimerów jest także możliwość ich zastosowania w leczeniu uszkodzonego rdzenia kręgowego. Metoda polega na wszczepieniu $\mathrm{w}$ miejscu ubytku rdzenia kręgowego PHB, pokrytego warstwa hydrożelu alginianowego, zawierającego fibronektynę. Macierzyste komórki nerwowe (ang. neural stem cells, NSCs) rosnace w matrycy z PHA moga wspomóc naprawę centralnego układu nerwowego. PHA wspomagały zarówno wzrost, jak i różnicowanie sie NSCs (XU i współaut. 2010). Obecnie na skalę przemysłowa produkowane sa cztery biopolimery:

- Biopol ${ }^{\mathrm{TM}}$ (kopolimer 3HB i 3HV) syntezowany przez $C$. negator, a ostatnio również przez zmodyfikowana genetycznie $E$. coli;

- Biomer ${ }^{\mathrm{TM}}$ (homopolimer 3HB) uzyskiwany w hodowlach $A$. latus;

- Nodax $^{\mathrm{TM}}$ (kopolimer 3HB i 3HV) otrzymywany $z$ udziałem zmodyfikowanego genetycznie C. necator,

- Biocycle ${ }^{\mathrm{TM}}$ (homopomlimer 3HB, kopolimer 3HB i 3HV) kumulowany przez Burkholderia sacchari (RUDNIK 2008).

\section{PODSUMOWANIE}

Polihydroksyalkanolany to biopolimery o ogromnym potencjale, mogące stanowić alternatywe dla obecnie powszechnie stosowanych tworzyw sztucznych. Wśród ich wielu zalet najważniejszymi są: podatność na biodegradację, biozgodność i właściwości mechaniczne zbliżone do właściwości polimerów syntetycznych. Moga być otrzymywane na 
drodze mikrobiologicznej i z roślin modyfikowanych genetycznie. Niestety, największym problemem zwiazanym $z$ PHA jest nadal zbyt wysoki koszt produkcji, wynikajacy $z$ trudności w oczyszczaniu. W celu obniżenia kosztów poszukuje się tańszych rozwiąań oczyszczania PHA i alternatywnych źródeł składników odżywczych dla drobnoustrojów, $\mathrm{m}$. in. $z$ odpadów przemysłu rolno-spożywczego. PHA sa bez watpienia biopolimerami, na których warto skupić uwage i podjać starania w celu rozwoju ich technologii, gdyż sa jednym $z$ najważniejszych kandydatów do zastapienia tworzyw sztucznych.

\section{Streszczenie}

W pracy omówiono polihydroksyalkanolany, biopolimery o ogromnym potencjale. Scharakteryzowano ich właściwości i zastosowanie, zwracając uwage na takie ich zalety jak biozgodność (brak toksyczności w stosunku do organizmu), podatność na biodegradację, czy właściwości termoplastyczne, zbliżone do tworzyw sztucznych. Niestety, pomimo wielu zalet, PHA nie sa powszechnie wykorzystywane, głównie ze względu na wysoki koszt ich wytwarzania i oczyszczania. Dlatego w celu obniżenia kosztów podejmuje się działania w kierunku zastapienia podczas hodowli drobnoustrojów źródła węgla tanimi materiałami odpadowymi. Kolejnym sposobem zmniejszenia kosztów produkcji PHA jest wykorzystanie modyfikowanych genetycznie mikroorganizmów. Alternatywa może być także poszukiwanie nowych metod wyodrębniania biopolimeru z komórek. Dobrym pomysłem może być także łączenie chemicznych i mechanicznych metod oczyszczania PHA. PHA bardzo często wykorzystywane sa w medycynie, zastępując tworzywa sztuczne, gdzie istotne sa właściwości materiałów oraz ich podatność na biodegradację. Niestety, ze względu na cenę, do wytwarzania polimerowych przedmiotów użytku codziennego, polimery syntetyczne wykorzystywane są częściej.

\section{LITERATURA}

ANiS S. N. S, NuRHEZREen M. I., Kumar S., AmiRUL A.-A., 2013. Effect of different recovery strategies of $\mathrm{P}(3 \mathrm{HB}-\mathrm{co}-3 \mathrm{HH})$ copolymer from Cupriavidus necator recombinant harboring the PHA synthase of Chromobacterium sp. USM2. Sep. Purif. Technol. 102, 111-117.

BORMANN E. J., ROTH M., 1999. The production of polyhydroxybutyrate by Methylobacterium rhodesianum and Ralstonia eutropha in media containing glycerol and casein hydrolysates. Biotechnol. Lett. 21, 1059-63.

Chen G., ZHANG G., PARK S., LEE S., 2001. Industrial scale production of poly(3-hydroxybutyrate-3-hydroxyhexanoate). Appl. Microbiol. Biotechnol. 57, 50-55.

Chen G.-Q., PAGE W. J., 1997. Production of poly-b-hydroxybutyrate by Azotobacter vinelandii in a two-stage fermentation process. Biotechnol. Tech. 11, 347-50.

Ciesielski S., PoKoJ T., Klimiuk E., 2008. Molecular insight into activated sludge producing polyhydroxyalkanolates under aerobic-anaerobic conditions. J. Ind. Microbiol. Biotechnol. 35, 805-814.

DE Koning G. J. M., Witholt B., 1997. A process for the recovery of poly(hydroxyalkano- ates) from Pseudomonas. Part 1. Solubilization. Bioproc. Eng. 17, 7-13.

DoI Y., KitAmuRA S., ABE H., 1995. Microbial synthesis and characterization of poly(3-hydroxybutyrate-co-3-hydroxyhexanoate). Macromolecules 28, 4822-4828.

FonsecA G. G., Antonio R. V., 2006. Polyhydroxyalkanoates production by recombinant Escherichia coli harboring the structural genes of the polyhydroxyalkanoate synthases of Ralstonia eutropha and Pseudomonas aeruginosa using low cost substrate. J. Appl. Sci. 6, 1745-1750.

JACQUEL N., LO C.-W., WEI Y.-H., WU H.-S., WANG S. S., 2008. Isolation and purification of bacterial poly(3-hydroxyalkanoates). Biochem. Eng. J. 39, 15-27.

JAU M. H., Yew S. P., TOH P. S., ChONG A. S., Chu W. L., Phang S. M., NaJimudin N., SuDESH K., 2005. Biosynthesis and mobilization of poly(3-hydroxybutyrate) [P(3HB)] by Spirulina platensis. Int. J. Biol. Macromol. 36, 144151.

KaUR L., Khajuria R., Parihar L., Dimpal Singh G., 2017. Polyhydroxyalkanoates: biosynthesis to commercial production - a review. JMBFS 6, 1098-1106.

KHANNA S., SRIVASTAVA A. K., 2005. Recent advances in microbial polyhydroxyalkanoates. Process. Biochem. 40, 607-619.

Khardenavis A., GuHa P. K., Kumar M. S., MuDLIAR S. N., ChAKRABARTI T., 2005. Activated sludge is a potential source for production of biodegradable plastics from wastewater. Environ. Technol. 26, 545-552.

KONDRATOWICZ F., 2010. Synteza $i$ właściwości biodegradowalnych kopoliestrów alifatyczno-aromatycznych. Rozprawa doktorska, ZUT, Szczecin.

Kosior E., BRAGANCA R. M., FOWLER P., 2006. Lightweight compostable packaging, literature review. The Waste \& Resources Action Programme, Banbury, Oxon, 18-20.

KUNASUNDARI B., SUDESH K., 2011. Isolation and recovery of microbial polyhydroxyalkanoates. EXPRESS Polym. Lett. 5, 620-634.

LaW K. H., LEUNG Y. C., LAWFORD H., ChuA H., WAI-Hung L., YU P. H., 2001. Production of polyhydroxybutyrate by Bacillus species isolated from municipal activated sludge. Appl. Biochem. Biotech. 91-93, 515-522.

LEE S., 1996. Review bacterial polyhydroxyalkanoates. Biotechnol. Bioeng. 49, 1-14.

Luengo J. M., GARCi $\square$ A B., SANDOVAL A., NAHARRO G., Olivera E. R., 2003. Bioplastics from microorganisms. Curr. Opin. Microbiol. 6, 251-260.

Madison L. L., Huisman G. W., 1999. Metabolic engineering of poly(3-hydroyalkanoates), from DNA to plastic. Microbiol. Mol. Biol. 63. 2153.

MusZyŃSKi A., ŁeBKowsKa M., KacZMARska J., WALETRZAK G., 2013. Badania czynników ograniczajacych pozyskiwanie polihydroksykwasów $z$ osadu czynnego. Ochrona Srodowiska 35, 19-23.

Padovani G., Carlozzi P., Seggiani M., Cinelli P., VITOLO S., LAZZERI A., 2016. PHB-rich biomass and $\mathrm{BioH}_{2}$ by means of photosynthetic microorganisms. 'CET 49, 55-60.

PARK S. J., SANG L.Y., YOUNG L., 2004. Biosynthesis of (R)-3-hydroxyalkanoic acids by metabolically engineered Escherichia coli. Appl. Biochem. Biotechnol. 114, 373-379.

RUDNIK E., 2007. Compostable polymer materials. Elsevier, Amsterdam, The Netherlands. 
SAHARAN B. S., GREwAL A., KUMAR P., 2014. Bio technological production of polyhydroxyalkanoates: a review on trends and latest developments. Chin. J. Biol. 1-18.

STEINBÜCHEL A., 2003. Production of rubber-like polymers by microorganisms. Curr. Opin. Microbiol. 6, 261-270.

Sudesh K., TAGUCHI K., DoI Y., 2001. Can cyanobacteria be a potential PHA producer? RIKEN Rev. 42, 75-76.

SuzUKI T., YAmane T., ShimizU S., 1986. Mass production of poly-beta-hydroxybutyric acid by fed-batch culture with controlled carbon/nitrogen feeding. Appl. Microbiol. Biotechnol. 24, 370-374.
TEKIn E., ATEs M., Kahraman O., 2012. Poly-3-hydroxybutyrate-producing extreme halophilic archaeon, Haloferax sp. MA10 isolated from Camaltı Saltern, Izmir. Turk. J. Biol. 36, 303312.

TRIPATHI A. D., YADAV A., JHA A., SRIVASTAVA S. K., 2012. Utilizing of sugar refinery waste (cane molasses) for production of bioplastic under submerged fermentation process. J. Polm. Environ. 20, 446-453.

Xu X. Y., Li X. T., PEnG S. W., XiaO J. F., LiU C., FAng G., Chen K. C., Chen G. Q., 2010 The behaviour of neural stem cells on polyhydroxyalkanoate nanofiber scaffolds. Biomaterials $31,3967-3975$.

KOSMOS Vol. 67, 2, 299-306, 2018

MatgorZata Mizielińska, ŁukAsz Łopusiewicz, Marcin Soból

Center of Bioimmobilisation and Innovative Packaging Materials, West Pomeranian University of Technology in Szczecin, Klemensa Janickiego 35, 71-270.Szczecin, E-mail: malgorzata.mizielinska@zut.edu.pl

POLYHYDROXYALKANOATES - PROMISING BIODEGRADABLE POLYMERS

Summary

This paper discusses properties of polyhydroxyalkanoates (PHA), biopolymers with a huge potential for practical applications. PHA have a number of advantages such as biocompatibility (no toxicity for organism), biodegradability and thermoplastic properties similar to those of synthetic plastics. Unfortunately, despite these advantages PHA are not widely used owing to the high costs of their preparation and purification. Therefore, in order to reduce these costs efforts are being undertaken to replace traditional carbon sources for cultivation of microorganisms by cheaper waste materials. Another way to reduce the cost of PHA production is the use of genetically modified microorganisms. An alternative approach may be also a search for new methods for extraction of these biopolymer from the cells including combination of chemical and mechanical methods of purification. PHA are very often used in medicine, because of their properties and biodegradability. In this area they substitute plastics. Unfortunately, costs of production from PHA polymeric objects for everyday use are still too high, so synthetic polymers remain predominantly in use.

Key words: biopolymers, microorganisms, plastics, polyhydroxyalkanoates 